\title{
De væsentligste indgreb og nationaliseringer i Chile (oktober 1970-august 1971)*
}




\begin{tabular}{lll}
$\begin{array}{l}\text { Form for } \\
\text { aktion }\end{array}$ & $\begin{array}{l}\text { Dato } \\
\text { omtr. }\end{array}$ & Virksomhed \& dens størrelse \\
\hline $\mathrm{R}$ & $11 / 70$ & $\begin{array}{l}\text { største tekstil(uld)virksomhed, Fabrica de Panos } \\
\text { Bellavista Tome, ejet af Yarur interesser og W.R. } \\
\text { Grace, } 1.350 \text { arbejdere. }\end{array}$
\end{tabular}

\begin{tabular}{ll}
\hline I** $11 / 70 \quad$ & et datterselskab til Northern Indiana Brass Co. \\
& $($ NIBSA), vigtigste producent af messingdele og \\
& ventiler.
\end{tabular}

I $\quad 11 / 70 \quad$ et datterselskab til Ralston Purina.

SP 12/70 Cia. Acero del Pacifico (CAP), Chiles største stålproducent.

N 1/71 Carbonifera Lota Schwager, Chiles vigtigste (og Latinamerikas største) kulproducent, ansvarlig for 85 pct. af Chiles kulproduktion, 9,800 arbejdere.

\begin{tabular}{lll}
\hline $\mathrm{SP}$ & $1 / 71$ & private chilensiske kommercielle banker. \\
\hline $\mathrm{N}$ & $1 / 71$ & Lanere Austral, tekstilvirksomhed. \\
\hline $\mathrm{N}$ & $1 / 71$ & INESA, cementfabrik. \\
\hline $\mathrm{SP}$ & $2 / 71$ & $\begin{array}{l}\text { Zig-Zag, største forlægger i Chile (udgiver Er- } \\
\text { cilla...). }\end{array}$ \\
\hline $\mathrm{SP}$ & $2 / 71$ & $\begin{array}{l}\text { R.C.A. } \\
\text { de tre største kobberminer, Chuquicamata, El Te- } \\
\text { niente \& El Salvador (som tilhører Anaconda \& } \\
\text { Kennecott). }\end{array}$
\end{tabular}


Begrundelsen for aktionen \& form for kompensation

arbejdede under fuld kapacitet.

produktionen faldt, og firmaet afskedigede sine 280 arbejdere. I juni 1971 erhvervede CORFO sig NIBSA's 50 pct.-andel for \$ 3 millioner.

havde importeret forringet maskindel i stedet for nye maskiner, som rapporteret. Firmaet var også underkapitaliseret.

nationalisering af væsentlige industrier, som skulle danne basis for et nyt nationalt metallurgisk kompleks. CORFO erhvervede de 45 pct. af CAP's aktier, som endnu var på private hænder, for 90,6 millioner dollars, som skulle forfalde over 3-8 år. CORFO ejer nu 100 pct.

genvinding af grundressourcer; regeringen erhvervede 51 pct. af aktierne og indgik kontrakt om 100 pct.'s ejerskab i fremtiden.

Central Bank begyndte at købe aktier i de kommercielle banker. September 1971 kontrolleredes de 19 banker af Chiles 22 private kommercielle banker.

Allende bekendtgjorde dannelsen af et statsligt tekstilselskab, baseret på de to store eksproprierede firmaer, Bellavista-Tome og Lanere Austral.

nationalisering af væsentlige industrier.

Chile bekendtgjorde salg af kobber direkte til Kina.

erhvervede aktier, fordi firmaet var på grænsen til fallit, havde ikke betalt sine 900 arbejdere i 4 uger. Staten planlægger at grunde et forlagskompagni på det.

får kontrol med distributionen; CORFO erhvervede en andel på 51 pct. (før besad det 33 pct.), og danner det første firma i den ny »blandede« sektor.

»delegerede vejledere« blev sendt til minerne for at unders $\emptyset$ ge dårlig ledelse. 
SP 3/71 Bethlehem-Chile Iron Mines, en af de største jernmalmsproducenter.

\begin{tabular}{lll}
\hline SP & $3 / 71$ & $\begin{array}{l}\text { ARMCO Chile, førende leverandør af materiel til } \\
\text { malmknusningen i mineindustrien. }\end{array}$
\end{tabular}

\begin{tabular}{lll}
\hline- & $4 / 71$ & Anaconda Sales Corp. \\
\hline $\mathrm{N}$ & $5 / 71$ & 5 store Yarur tekstilvirksomheder.
\end{tabular}

\begin{tabular}{lll}
\hline WS & $5 / 71$ & Ford Motor Co.-virksomhed. \\
\hline SP & $5 / 71$ & $\begin{array}{l}\text { LIPIGAS og SERVIGAS, 2 private producenter } \\
\text { af flydende gas. }\end{array}$ \\
\hline- & $5 / 71$ & \\
\hline- & $5 / 71$ & 14 tekstilspinderier. \\
\hline SP & $5 / 71$ & $\begin{array}{l}\text { Anglo-Lautaro Nitrate Co., kontrolleret af Gug- } \\
\text { genheims, ansvarlig for næsten } 80 \text { pct. af nitrat- } \\
\text { produktionen. }\end{array}$ \\
\hline SP & $6 / 71$ & $\begin{array}{l}\text { Bank of London and South America (BOLSA) } \\
\text { med 10 afdelinger. }\end{array}$ \\
\hline I & n.a. & $\begin{array}{l}\text { El Melon og Cerro Blanco, de 2 største cementpro- } \\
\text { ducenter, som i 1964 var ansvarlige for omkring } \\
87 \text { pct. af industriens kapacitet. }\end{array}$ \\
\hline SP & $7 / 71$ & \begin{tabular}{l} 
Bank of America, med 8 filialer. \\
\hline
\end{tabular} \\
\hline
\end{tabular}


genvinding af grundressourcer; CORFO erhvervede Bethlehems to miner og tilknyttede faciliteter for 25 millioner dollars, som skulle betales over 17 år, begyndende juli 1973 .

nationalisering af væsentlige industrier; det regeringsejede Cia. Acero del Pacifico erhvervede 35,7 pct. af ARMCO's andel. Regeringen planlægger at overtage majoriteten af aktierne i alle firmaer, som tilvirker stål - INDAC, RODINSA, ARMCO, COMPAC, SOCOMETAL og INCHALEM - for at bygge et større integreret metallurgisk kompleks.

opnåelse af kontrol med distributionen. State Copper Corp. (CODELCO) overtog salget af kobber, men blev udsat for alvorlig international pression, da det oprettede handelsagenturer i udlandet.

anbragt under statens forvaltning - for at blive brugt som basis for den ny statsejede tekstilindustri.

arbejdere besatte virksomheden, efter at selskabet havde bekendtgjort afskedigelse af 400 arbejdere (ud af $i$ alt 600).

nationalisering af væsentlige industrier; statens olievirksomhed, ENAP, dannede et datterselskab ENADI, som skulle ordne distribution og salg af flydende gasser, brændstoffer, smøreolier og biprodukter fra petroleum.

statsvirksomheden, GASMA, dannes for at bygge og drive en rørledning til naturgas fra Punta Arenas til større chilensiske byer.

arbejdere beslaglagde samtidig 14 tekstilmøller. Beslaglæggelserne blev fulgt af statens beslaglæggelse for at opretholde produktionen.

genvinding af grundressourcer; CORFO erhvervede aktier for 8 millioner dollars, som skulle betales på 10 år.

nationalisering af bankvæsen; staten overtog den første udenlandske private kommercielle bank; kompensation skulle betales over 5 år.

indgreb på grund af faldende produktion, hvilket bragte bygge- og anlægsvirksomhed $\mathrm{i}$ fare.

nationalisering af bankvæsen; staten overtog B of A's aktiver for 2,5 millioner dollars. 


\begin{tabular}{|c|c|c|}
\hline SP & n.a. & $\begin{array}{l}\text { Cerros mine Rio Blanco (4.-største kobbermine i } \\
\text { Chile). }\end{array}$ \\
\hline $\mathrm{N}$ & $7 / 71$ & $\begin{array}{l}\text { alle større kobberminer (Anaconda, Kennecott \& } \\
\text { Cerro datterselskaber). }\end{array}$ \\
\hline- & $7 / 71$ & Kennecott. \\
\hline WS & $8 / 71$ & $\begin{array}{l}\text { Cervecerias Unidas, bryggerimonopolet (med } \\
\text { indflydelse fra Edwards), og INSA (med General } \\
\text { Tire-rettigheder), største producent af dæk og ak- } \\
\text { kumulatorer. }\end{array}$ \\
\hline- & $8 / 71$ & En Ford Motor Co.-fabrik. \\
\hline $\mathrm{N} / \mathrm{SP}$ & $9 / 71$ & $\begin{array}{l}\text { I.T. \& T., telefon Co. som betjente det meste af } \\
\text { landet. }\end{array}$ \\
\hline SP & $9 / 71$ & General Motors samlefabrik for lastbiler i Arica. \\
\hline $\mathrm{I} / \mathrm{N}$ & $9 / 71$ & $\begin{array}{l}\text { General Tire's chilenske datterselskab, INSA, stør- } \\
\text { ste producent af dæk og slanger. }\end{array}$ \\
\hline $\mathrm{N}$ & $9 / 71$ & $\begin{array}{l}\text { MADECO, største fremstiller af kobberprodukter. } \\
\text { Ejet af General Cables Corp. (N.Y.) og Fiat (Mi- } \\
\text { lano, Italien). }\end{array}$ \\
\hline $\mathrm{N}$ & $9 / 71$ & First National City Bank's 8 chilenske kontorer. \\
\hline $\mathrm{N}$ & $10 / 71$ & $\begin{array}{l}\text { E.I. Dupont, fabrik for sprængstoffer, den største } \\
\text { i Sydamerika. }\end{array}$ \\
\hline
\end{tabular}


genvinding af grundressourcer. Cerro Corp. gik ind på at sælge sin mine, Rio Blanco, for 55 millioner dollars, hvis regeringen vil overtage dens gæld på 56 millioner dollars til U.S. Eximbank.

genvinding af grundressourcer. Grundlovsændring for nationalisering af kobberminerne enstemmigt vedtaget af Chiles Kongres.

kontrol med distribution. CODELCO overtog salg af kobber, produceret i El Teniente.

arbejderne besatte de to største fabrikker, idet de beskyldte dem for dårlig administration.

resultat af arbejderovertagelse (maj 1971) og delvis resultat af nationalisering af bilindustrien. Fiat vil drive virksomheden og samle 3.000 lastbiler om året.

nationalisering af de nødvendigste tjenester. I.T. \& T. påstår, at deres aktiver er værd 153 millioner dollars, mens Chile hævder, de er 24 millioner dollars værd.

G.M. ønsker at sælge ud, december 1971, på grund af »begrænsninger « pålagt af Chiles regering.

nationalisering af væsentlige industrier. Regeringen prøver at skabe et dækmonopol ved at kombinere INSA med MANESA (en tidligere Firestonevirksomhed, overtaget af regeringen).

der blev grebet ind på fabrikkerne for at undgå mangel på forsyninger i industrien.

nationalisering af bankvirksomhed. Aktiverne, der er 3,5 millioner dollars værd (bogført værdi), skal sælges for 4,55 millioner dollars til Chiles regering.

nationalisering af væsentlige industrier. 